\title{
PERCEPÇÃO SUBJETIVA DE ESFORÇO EM SITUAÇÕES DE JOGO NO FUTEBOL DE 7
}

\section{Henrique Ims Bortolozo (IC)}

\section{Resumo}

O aumento dos níveis físicos, técnicos e táticos dos atletas com deficiência durante a prática competitiva no desporto paralímpico ao longo dos anos é incontestável. Sendo assim, indicativos que estabeleçam maiores compreensões da demanda de esforço durante os jogos contribuirão para maior entendimento da intensidade e complexidade das ações realizadas durante os jogos.

Palavras Chave: Esporte Paralímpico, Paralisia Cerebral, Treinamento Desportivo.

\section{Introdução}

O futebol de 7 é modalidade paralímpica no qual os atletas que praticam a modalidade são portadores de paralisia cerebral. São exigidos por parte dos atletas, elevados níveis de força, velocidade e resistência para suportar a demanda de esforço durante os jogos. O treinamento passa a requisitar modelos que indiquem programas para maximizarem tais capacidades físicas. Nesse sentido, o controle da carga de treinamento será imprescindível para resultados positivos dentro do processo de preparação desportiva do atleta.

\section{Resultados e Discussão}

Este estudo analisou a percepção Subjetiva de Esforço e de Recuperação, através da Escala CR10 de Borg (1982) modificada por Foster et al. (2001), e pela escala de Kentaa (1998) durante o 15 Campeonato Brasileiro de Futebol de Sete, no qual foram analisados dois jogos de duas equipes. Para a tabulação de dados foi utilizado o software Microsoft Excelß 2010. Antes de iniciar os jogos, foi perguntado aos atletas à sua percepção de recuperação (PSR) (Kentaa et. al., 1998) e, imediatamente ao final do primeiro e segundo tempo, em relação à percepção subjetiva de esforço (PSE).

Foram obtidas 46 respostas de PSR e PSE. Diante dos dados referentes à PSR, foi observado que as duas equipes estão com valores maiores no primeiro jogo quando comparado ao segundo. Em relação à PSE, foi observado que foi realizado menor esforço no primeiro jogo em relação ao segundo pela equipe $A$, visto que na equipe $B$ o esforço foi maior na primeira partida $e$ menor na segunda.

\section{Conclusões}

Conclui-se que apesar do baixo número de jogos analisados, a equipe $B$ demonstrou, por suas respostas, maior PSE do que a equipe $A$, ou seja, os jogos tiveram uma carga de esforço grande $e$ suas respostas ligadas à PSR para o segundo jogo são maiores do que a equipe $A$, demonstrando assim um estado de recuperação melhor bem como melhor nível de condicionamento físico em relação à equipe $A$. Dessa forma, espera-se compreender os níveis de intensidade durante as partidas de futebol de 7 , a recuperação desses atletas durante a competição e auxiliar treinadores na prescrição, controle e monitoramento das sessões de treinamento dos atletas praticantes de futebol de 7.

\section{Agradecimentos}

Agradeço à Deus, ao meu orientador, José Irineu Gorla, à minha família e à minha namorada por todo o apoio prestado durante a realização deste trabalho.

BORG, G. A. Psychophysical Bases Of Perceived Exertion. Medicine and Science in Sports and Exercise, Madison, v. 14, no. 5, p. 377-381, 1982.

KENTTÄ, G.; HASSMÉN, P. Overtraining and recovery. A conceptual model. Sports Medicine, v. 26, n. 1, p. 1-16, 1998. 